\title{
A New Interpretation of Catherine's Characters in Wuthering Heights
}

\author{
Kang Haibo
}

Baicheng Normal University

Kew Words: Characters; Wuthering Heights; Catherine

\begin{abstract}
Introduction of Emily Bronte and Wuthering heights story synopsis. Emily Bronte (1818-1848), a British novelist in the 19th century , is one of the famous "Bronte sisters" of British literary history. Although the woman writer spent only 30 years in the world then quietly left, her only novel Wuthering heights (1847) has established her status in English literature and world literature history. Wuthering heights is about a sad love story: a gypsy foundling named Heath Cliff is adopted by the old master of wuthering heights, then go out to get rich for shame and failure in love, at last he comes back for crazy revenge. The full novel is filled with a strong fighting spirit against oppression and striving for the happiness, and always shrouded in mysterious and romantic tension. At the beginning of publishing, the novel it has been regarded as a naive fantasy of young women writers from the reality, but soon it was highly praised by the critics and was warmly welcomed by the readers. The heroine, Catherine, has always been a favorite figure in British literature, so it is necessary to make a comprehensive and systematic study of her image.
\end{abstract}

\section{A new interpretation of Catherine's characters}

\section{True Catherine}

Catherine in Greek means pure, so true Catherine refers to the childhood innocence, honest and true of Catherine's character on the one hand. The story of Wuthering heights took place in the wild natural environment of Yorkshire in the British, and the opening of the full text has a section depicting the natural landscape of wuthering heights "the sceneries here are excessive tilt and small firs, and narrow windows deeply embedded in the wall, corners protected with large protruding stone. With a layer of black ice, land is frozen hard, and rugged and irritable Earnshaw lived here." It can be seen that wuthering heights is a wilderness and remote village, and everything of village is original. The heroine Katherine grew up in such an environment, naturally have to cultivate the happiness, indulgence, rough, wild, unrestrained personality without fear, shy, reserved, timid. Of course, this is also one of the most true of original ecological character, should be approved. True Catherine on the other hand refers to the truth feelings of her and Heath Cliff. Heath Cliff, as a outcast from the doggery, met with a cold shoulder when he just entered the wuthering heights. The hostess of heights hates him, Hindley master envies him, even the servants dare to bully him. Only Catherine regards him as a friend. When the old Earnshaw was alive, everyone but Catherine does not like him, but because of the old master's asylum, Heath Cliff's life is OK, however, when the old master died, his situation has gone from bad to worse. In this desolate cold world, he has nothing except Catherine, and Catherine also does not have other friends except Heath Cliff. Their similar characters, same life fun and rebel targets, make each other's survival as a condition of their existence. Heath Cliff loses his heart to the lively, stubborn, and wild girl, only she can give him 
understanding and friendship, and Catherine has realized to obtain full humanity, to get the real freedom, equality and dignity, only thoroughly stood together with Heath cliff. The love of two people initiate in the misfortune and resistance of this common initiation. Catherine's love for Heath Cliff is self seeking and truth bursting, she had the words "my love for Heath Cliff will never change like the mountain rock", this is the most true feelings reveal, and there is a meaning that when mountains have no edges, heaven and earth close, I will dare to separate from you. The love between them is the fit of a kind of the original mind force of the most pure heart, without a bit of secular infection, to pure, true, sacred.

\section{Sad Catherine}

In the title of Wuthering heights, the female writer has set the tone for the protagonist's tragedy."Wuthering" refers to a roar from the nature when the storm swept through, the violent storm will destroy all the trees of the heights, will distort the "tree", which is the symbol of human nature in the works. That is to say, all human nature will be destroyed under the storm, and the main character in the books will be doomed to tragedy.As for Catherine's tragedy can be unfolded from the following angles.First, she doesn't get fathers and brothers love.Second, she can not be together with the one she loves forever.Third, the marital relationship is not harmonious.Specific analysis is as follows: Catherine is a boyish girl, and her character has a rough, wild, stubborn and rebellious side, which is her true temperament. There is such a scene in the book: when the girls with the same age of Catherine are playing with dolls, she likes horseback riding, when her father asks her what gift she wants, she incredibly wants a horsewhip less than 6 years old. Obviously, this character is not in line with the girl's aesthetic standards in the patriarchal society, so Catherine naturally can't get his father's love.After his father died, her brother Hindley demoted Heath Cliff to servants, at this time Catherine stood on Heath Cliff's side, against his brother together with him, predictably, as a representative of the new patriarchal society, Hindley could not like his sister against him with outsiders. According to the analysis of the 2.1, Catherine and Heath Cliff's love is sacred and long, and the one party will not be able to survive without love, and the love is the love of nature, the original love, the love of spirit, the love of the soul.But the lovers can not ends well, just imagine, for a woman, this will be a lifetime of regret, so sad Catherine is reflected by the matter. Of course, investigate its reason, in addition to the social factors, Catherine herself has unshirkable responsibility. Indeed, from the perspective of traditional ideas, Catherine is a rich girl, but Heath Cliff is a sponsor of the orphans. They are between families of unequal social rank, and family status and hierarchy of the patriarchal society determines the combination of two people is very difficult. Even if there is the possibility of combining, the result is not too optimistic. Because, after all, they can't live in isolation, they still have to live in the society, living in the eyes of others. In addition, when Catherine meets with gentle master Linton, her heart has the seeds of the 
materialistic, secular and vanity in breeding.Her life value is in the change, the impact of modern civilization in Catherine heart is hard to resist. And she has a naive thought that after marrying Linton she can use Linton's property to help Heath Cliff promote his status, can put him in the position out of authority of her elder brother Hindley. She actually didn't realize that marrying Linton will break the harmonious love between her and Heath Cliff, then her tragedy begins with the destruction of harmonious love. After married with Linton, Catherine had never keep her husband in the heart, and Heath Cliff is still her dreamed spirit lover. Master Linton can only bring her rich life, and Heath Cliff is irreplaceable in the spiritual level, so the strange bedfellows of the husband and wife life can only bring endless quarrel and suspicion, then disharmonious married life for Catherine is a tragedy. If we analyze this kind of sadness, I think Catherine should bear the main responsibility. As a married woman, now that she has known to be unable to get together with lover, which is her own choice, she should accept the reality and settle in marriage. In marriage, she should at least consider her feelings, only the couple trust each other and understand each other, both sides of husband and wife are harmony, and family is stable. And Catherine's actions have already touched the bottom line of Linton, after all, a man will not tolerate his wife to enjoy the rich life of their own, while the heart is filled with another man. I think although the female writer Emily has not experienced the love and marriage life, her real intention should not advocate such a disharmonious marriage.

\section{Ruthless Catherine}

Catherine's ruthlessness can be analyzed as follows. First, she and Heath Cliff stood together against brother, which is ruthless to her brother. Second, her choice to marry Linton is ruthless to Heath Cliff, even betrayal. Third, her miss of Heath Cliff after marriage, and the tryst after Heath Cliff's return are ruthless to her husband. In particular, Hindley's envy of Heath Cliff is just because he thinks he took away his father's love, and Hindley's original intention is not to break up the good friends of Catherine and Heath Cliff.Therefore, there is no need to decisively fight against her elder brother with Heath Cliff together for Catherine, and this action can only arouse Hindley's more and deeper hate to Heath Cliff. Below discuss choosing their marriage to Catherine Heath Cliff's cruel. The following is about Catherine's ruthlessness to Heath Cliff in the choice of marriage.After returning from the Thrushcross Grange, the vanity of Catherine began to sprout. In her heart of hearts though she still loves Heath Cliff, she begins to shake under the impact of the powerful secular civilization. That is to say, as a rich woman, Catherine is impossible to not be affected by the secular society, because the pancake is not bigger than the pot, which still makes sense. Catherine understands in her heart, although Heath Cliff's social status, behavior and meters are inferior to Linton, she is unable to forget the love for Heath Cliff. But she also thinks marrying Heath Cliff will reduce identity, if she marry Heath Cliff, there is only poor waiting for them in the 
future, which is unacceptable for Catherine as a rich woman. Finally, in this kind of contradiction and pain, she made a decision: marrying Linton. I think at this point, Catherine has betrayed the love between her and Heath Cliff, her choice is ruthless to Heath Cliff, the departure of Heath Cliff is the most direct and true portrayal of the ruthlessness. However, Catherine's marriage is not as good as the imagine, and material abundance let her spirit more lonely, so she has more attachment to his spiritual lover with love sickness in night and day. In Linton's opinion, marriage is sacred, exclusive, and selfish, a woman should not love her husband, but also attached to their lover. In this sense, Linton is a representative of the patriarchy. Catherine always thought of Heath Cliff is is ruthless betrayal of her husband, and after Heath Cliff's return, their tryst pushes the heartless betrayal to the extreme. Actually, in the triangular relationship among them, it is not hard to see self-deception of Catherine. I think she wants to eat fish and bear paw, and she not only wants Lady rich life, but also wants Heath Cliff to comfort her lonely soul, longing for free life without separating herself from the lure of the civilized world, which fully shows the selfish and heartless side of Catherine.

\section{Contradictory Catherine}

The analysis of the Catherine characters can be cut from the following several of contradiction. First of all, the contradiction between fantasy and reality.In the beginning Catherine had naive fantasy, who thinks to marry Linton "can help Heath Cliff promote to a higher position, and put him in the position out of authority of her elder brother Hindley", but the reality breaks the illusion of Catherine. Her marriage with Linton did not have to help Heath Cliff, instead led his bloom away. Once again, the contradiction between vanity and true love. Her choice of Linton as husband contains many real purposes of vanity in addition to the secular society concept. Catherine herself said frankly, "he will have a lot of money in the future, I will be the most distinguished woman here, and I will be proud of such a husband." In addition, she also repeatedly stressed true love with Heath Cliff, which is "the central idea of her life is he, if everything is else destroyed, only he is still there, I can continue to live; if all else is still there, but he disappeared, the world will be a very strange place for me, I won't be part of it." Through the above quotation, it is not hard to see Catherine's love for Heath Cliff is real, but when Heath Cliff ran away, she did not go with him, and continued to live a life as a wealthy woman, which embodies the vanity of her character. Furthermore, when Heath Cliff returned, she not only wants to have Linton's rich, but also lets Heath Cliff to comfort her lonely soul, longing for free life without separating herself from the lure of the civilized world, which fully shows the selfish side of Catherine.

In a word, through the above several aspects, a new image of Catherine displays in real: Catherine is a new women with androgyny not afraid of the patriarchal society, so respectable; Catherine is a contradiction of the tragic figure, so pitiful; She has a 
psychological imbalance, so sad.

\section{References}

[1] WangJun. Acritical Appreciation of British and American Women Writers [M] . XinHua Press. 2007

[2] Wilfred L Guerin, Earle Labor, Lee Morgan, Jeanne C.Reesman, John R. Willingham. A Handbook of Critical Approaches to Literature(The fourth edition) [M]. Foreign Language Teaching and Research Press and Oxford University Press, 2004.

[3]Zhu Gang.Twentith Century western Critical Theories [M]. ShangHai Foreign Language Education Press,2001.

[4] Chang Yao xin. Notes on English and American Literature [M] . Naikai University Press,2004 [5]LiuBingshan, Ashort History of English Literature [M]. Henan People’s Pubishing House, 2007 